\title{
HILANDAR COLLECTION - A UNIQUE TREASURY OF UKRAINIAN MANUSCRIPT HERITAGE
}

The article deals with the progress and preservation of Slavic (Ukrainian) cultural heritage in Greece, on Mount Athos and in Hilandar monastery. The article describes Slavic manuscript heritage of the monastery. Attempts are made to reveal examples of Ukrainian manuscripts from the general Slavic fund of the monastery. There is also given characteristic describing the synthesis of available in collection Slavic manuscripts in general.

Key words: Hilandar, manuscripts, Slavic (Cyrillic) and Ukrainian examples, traditions, heritage.

Addressing to issues of parallelism and features of development of the spiritual culture of Ukraine and Greece, St. Mount Athos is clearly singled out as one of the aspects of the problem. In addition, Mount Athos is a world cultural treasury in general, it is also a treasury of Slavs. As well as in Greece, among numerous Greek relics, Slavic heritage was revealed in Athos monasteries, it gives opportunity to learn about Ukrainian culture taking into consideration monuments kept in Greece. Before writing the article there were conducted numerous researches dedicated to traditions and cultural property of Ukraine that is kept in Athos monasteries. This article is regarded to development and reservation of Slavic (Ukrainian) manuscript heritage in Hilandar monastery. This monastery is considered to be the Slavic-Serbian, but it was the first that have got translation of the Ostrog Bible from Ukraine.

The object of the work is Slavic (Cyrillic) manuscript heritage, which contains Ukrainian manuscripts.

The subject of the work is Hilandar monastery and traditions which contribute to preservation of great number of Slavic manuscripts.

Tasks of the work are: to reveal Ukrainian examples from the general manuscript fund of Hilandar monastery; to elucidate traditions of development of Slavic culture in Hilandar monastery; to make an attempt to find figures of the Ukrainian monasticism, who contributed to the development and preservation of Ukrainian cultural traditions on mount Athos.

The most numerous researchers of monastery and its manuscript funds are Serbs. That's why the monastery name is «Slavic-Serbian». The main source of researches is catalogue of D. Bohdanovych Catalogue of Cyryllic manuscripts of Hilandar monastery [1]. But many memories of this monastery have travellers, ambassadorial missions, monks and clergy. There can be outlined three main sources in this list: V. Hryhorovych-Barskyi (XVIII century) [2], Porfiriy Uspienski (XIX century) [4, 5], Niktariya MakLiz (XX century) [3]. However, the main sources of the research are manuscripts. 
Hilandar monastery is dedicated to feast of Presentation of the Blessed Virgin Mary. There are a few versions about origin of the monastery name $\mathrm{X} \imath \lambda \iota \alpha \nu \delta \alpha \rho \imath \mathrm{v}$. The first version is confirmed by documents of X century where name of the founder of monastic community of the monastery is written-George Hilandar. The second version is more interesting and romantic. According to it the monastery name is Hilandar because it is similar in shape to the Byzantine boat "helandion".

According to the Greek translation of name there can be outlined one more version.

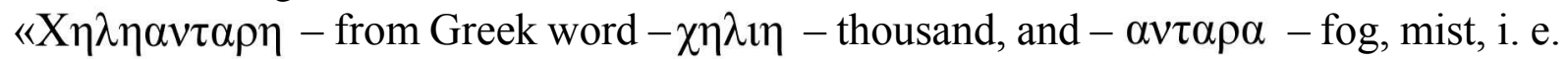
«thousands of fogs». There is an interesting history of this version. Invaders tried to come into monastery that they saw from the mountain many times, but after going down in the valley they were hit by dark cloud that did not allow them to see themselves, each other, they lost way and wandered. They climbed the mountain again and again and the same things repeated. It happened many times again before leaving of invaders.

There is one more version, that monastery was named in honour of tract Hilandar -

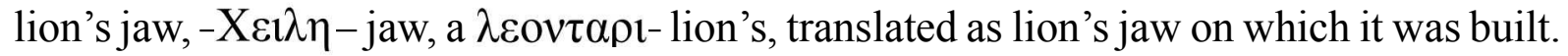
This name is confirmed by a few reasons. Name of city - in place of monastery was built and in front of its gates was built a huge lion; the name of the island, in front of the monastery on the rock of which, like into a lion's jaw inattentive ships came; shape of the plain, that was alike to lion's jaw surrounded on three sides by «mountains-mane» etc.

Name «thousand men» is also present $\mathrm{X} \sigma \lambda \sigma \alpha-$ thousand, $\alpha \nu \delta \rho \circ \varsigma-$ men. This version is connected with pirates who tried to rob the monastery. Pirates beforehand divided in two groups and killed each other in dense fog.

The founders of monastery in XII century are considered to be Serbian rulers Stefan Nemania and his son Rastko. Rastko inherited Serbian throne after his elder brothers. But instead of that he became a monk with name Sava. So the monastery was built due to St. Stefan costs, Serbian king, son-in-law of Greek autocrat Roman. That was the first combining of Slavic and Greek blood and cultures.

V. Hryhorovych-Barskyi name Hilandar monastery as Hilandar Lavra because of building greatness and beauty and richness of the area where the monastery is located. It was passed for lifelong Serbian ownership in 1198 by order of Emperor Alexiy III.

Hilandar, Slavic-Serbian monastery on Athos, educated spiritual bishops and patriarches for Serbia. Translations of spiritual literature and works of Holy Fathers from Greek into Slavic were made in the walls of the monastery and served as the main source of spiritual enlightenment of Serbia and other Slavic nations.

Hilandar was active during the period of Turkish occupation unlike other monasteries that have lost benefactors with the fall of the Byzantine. Decay of the monastery became in XVII century when Turks prohibited autonomy in Serbia and made the country submit to World Patriarch of Constantinople who served as both spiritual and secular ruler of the Christian subjects of the Ottoman Empire. Instead of Serbian monks Ukrainians, Bulgarians and Vlachs came there. Till the end of XVIII century the monastery was mostly Bulgarian. Only later Serbian king Alexandr II, assisted in restoring the monastery after fires in 1722 and 1891.

The Divine Liturgy is served exclusively in Church Slavonic language, but with Serbian accent. Reading and singing match to Athos statute. There are small differences in Divine 
Liturgy practice that are connected with adoration to the icon of the Holy Virgin by the monastery. On Divine Liturgy there are sung short Serbian songs, on Sundays songs are sung Serbian (in Church Slavonic language with Serbian accent) long Greek chants. The monastery has great treasury and library with a huge collection of Slavic manuscripts. Among valuable books that are kept in the monastery there is a royal gospel written in gold in two lines. There are 50 christodules also. Some of them are written on parchment, some - on paper. With existing in monastery christodules there can be seen that this monastery was favorite one of Serbian and others Orthodox rulers and endowed with various blessings from them. Because as usual christodul is supported by contribution of someone who donates.

During examination of Slavic manuscript (Cyrillic) fund, among 1150 manuscripts, there was chosen certain number of artifacts interesting in language or content, there were also revealed patterns of Ukrainian tradition.

We managed to research manuscripts only due to materials - short movie clips that were provided by the center of manuscripts of Moni Vlatazon in Saloniky. This remarkable place on earth where there is a foot imprint of Paul the Apostle, where he proclaimed his epistle to Solunians.

Like previous collections researched in Athos, Hilandar collection is not an exception. From X to XVI centuries - these are manuscripts of Serbian and Bulgarian pronunciations. There are examples of Romanian and Moldavian-Vlachs traditions. Starting with XVI century and till XVIII century, geography is extended to Ukraine and Moscow. The study was conducted using a variety of methods: semiotic (language and through filigree), ethnic semiotic, method of liturgical practice etc.

Ukrainian examples are: Вибрані євангеліє ієромонаха Романа (Selected Gospels of fr. Roman), 1337 [6], Чотирисвангеліс (Four Gospels of middle XVI century), Moldavian edition with Galician-Ukrainian elements, (Ukrainian. - L. T.-K.) [7], Чотириєвангеліє з Дрогобича (Four Gospels from Drohobych) - 1612 [8], Чотириєвангеліє (Four Gospels of XV century), Rus edition with Galician-Moldavian elements (Ukrainian. L. T.-K.) [9], Праксапостол волинський (Volhynian Praksapostol) - beginning of XVII century, Ukrainian-Volhynian edition - (No 71 Katalog by D. Bohdanovych [1]) [10], Псалтир з послідуванням (Psalter with Followings), 1614, written by monk Elijah from Moldova. Serbian edition, but Rus-Moldavian (Ukrainian. - L. T.-K) notes [11], Lviv Four Gospels 1615-Galician-Volhynian edition [12], Псалтир (Psalter of first quarter of XVI century), Ukrainian [13], Тлумачний псалтир (Interpretative Psalter), Ukrainian [14], Псалтир з тлумаченням (Interpretative Psalter of XVII century), Ukrainian [15], Псалтир (Psalter XVII century), Ukrainian [16], Лiствиия (The Ladder of Divine Ascent) 1500, Ukrainian edition [17], Лістивия Супрасльська (The Ladder of Divine Ascent, Suprasal), 1530. It was written by monk Arseniy in monastery of Annunciation and John the Apostle; Ukrainian (or Belarusian). [18], Слова Св. Отиів (Homily of Holy Fathers), Rus (Ukrainian) and Moldavian edition of XVI century [19], Роздуми про християнські страждання (Meditation on Christian Sufferings of Saint Dymytriy of Rostov (Danylo Tuptalo), XVIII century) [20], Aпокриф (Biblical Apocrypha), 1766, Church Slavonic language (Ukrainian. L. T.-K.) [21], Ізводи з Феофілакту (Voices songs from Feofilakt of XVIII century), Church 
Slavonic language (Ukrainian. - L. T.-K.) [22], Повчальні слова (Hотіly of XVIII century), Church Slavonic language (Ukrainian. - L. T.-K.) [23], Collection by Ray Kalista and Iyenamiya Xaniopula of the end of XVIII century, Church Slavonic language (Ukrainian - L. T.-K...) [24], Ray Kalista anshymkude, XVIII century, Church Slavonic language (Ukrainian. -L. T.-K.) [25], Цветособраніс Iлії Скдіту (Flowers Collection of Elijah Yedikt of XVIII century), Church Slavonic language (Ukrainian. - L. T.-K.) [26], Збірник (Collection of XVIII century), Church Slavonic language (Ukrainian. - L. T.-K.) [27], Мінея за листопад (Menaion of November), Half-Statute of Rus-Moldavian Pattern (Ukrainian. - L. T.-K.), $3^{\text {rd }}$ Part of Quarter XVI Century [28], Мінея за лютий (Menaion of February), 1708, Church Slavonic language (Ukrainian. - L. T.-K.) [29] etc. This list can be filled up by 44 manuscripts. Therefore among 1150 worked out manuscripts of Hilandar monastery only 73 artifacts have Ukrainian traditions, only 73 manuscripts are patterns of Ukrainian culture. As already mentioned, it is basically XVII - XVIII centuries. But presence of these patterns in collection of SlavicSerbian monastery means that: 1 ) there were Ukrainians among local monastery community; 2) Ukrainian Manuscripts emigrated over the world; 3) In the collection there are examples of Ukrainian pronunciation, (not elements of Ukrainian edition in manuscripts of other languages);

Slavic collection of Hilandar monastery is demonstrative collection of Athos heritage. Vasyl' Hryhorovych-Barskyi was right standing that this collection has basically and theological content. During the research there were revealed philosophical, medical, juridical, didactic, historical and astronomical works etc.

Keeping artifacts in short movie clips and digitizing on modern devices will definitely help to save and research this treasure, but the best way to support own culture is good publishing with scientific exploring. There should be worked out 73 Ukrainian manuscripts from collection of Hilandar monastery on Athos. They are waiting for its researcher and maybe even some of them will be published.

\section{References:}

1. Bohdanovych D. Cataloh hirilosnih rukopisa monastira Khlandara. / D. BohdanovychBelgrad 1978. Tом 1,- 321 p. 2. Grigorovich-Barsky V. Traveling on the descent of the holy places by 17231747 / Vasily Grigorovich-Barsky. - Kyiv: osnovi 2000. - 767 p. 3. Mak Liz N. Evlogite. /Nektariya MakLiz. - Moscow, 2009. - 1133 p. 4. Uspenskyy P. The second putyshestvye by St. Alas Description skytov Athos and Mount Athos. /Parfyryy Uspenskyy. - Moscow, 1880, 528 c. 5. Uspenskyy P. FIRST putyshestvye in afonskye monasteries and skytbl. // Parfyryy Uspenskyy. - Moscow, 2006. - 1286 p. 6. Vybrani Evangeliya ieromonaha Romana 1337 ea.., (No 9 in Katalog of D. Bohdanovych [1]). 7. Chotyryevangelie XVI cm (No 41 in Katalog of D. Bohdanovych [1]). 8. Chotyryevangelie th Dragobicha 1612 ea. (No 43 in Katalog of D. Bohdanovych [1]). 9. Чотириєвангеліє XV cm. (No 66 in Katalog of D. Bohdanovych [1]). 10. Proxapostol valynsky XVII c. (No 71 in Katalog of D. Bohdanovych [1]). 11. Psaltir z posliduvannuam 1614 p., raid monah Illiya z Moldavii (No 95 in Katalog of D. Bohdanovych [1]). 12. Lvivske hcotyryevangelie 1615 ea. (No 110 in Katalog of D. Bohdanovych [1]). 13. Psaltir XVI c. (No 113 in Katalog of D. Bohdanovych [1]). 14. Tlumachny psaltir (No 116 in Katalog of D. Bohdanovych [1]). 15. Psaltir z tlumachennyam XVII c. (No 117 in Katalog of D. Bohdanovych [1]). 16. Psaltir XVII c. (No 156 in Katalog of D. Bohdanovych [1]). 17. Listvytcya 1500 ea. (No 184 in Katalog of D. Bohdanovych [1]). 18. Listvytcya Cupraslska 1530 ea.; reaid 
monah Arseny in monastir Blagovichshennya end Ioana Bogoslova (No 185 in Katalog of D. Bohdanovych [1]). 19. Slova Cv. Otetc Ruska (No 189 in Katalog of D. Bohdanovych [1]). 20. Rozdumy pro hrystiyansky strajhdannya St. Dimitriya Rostovsky, XVIII cm. (No 192 in Katalog of D. Bohdanovych [1]). 21. Apokrif; 1766 p. (No 193 in Katalog of D. Bohdanovych [1]). 22. Izvody z Feafilaktu XVIII c. (No 194 in Katalog of D. Bohdanovych [1]). 23. Povchalny slova XVIII cm. (No 195 in Katalog of D. Bohdanovych [1]). 24. Izbornyk Raij Kalista end Ienamiya Kcaniopula XVIII c. (No 196 in Katalog of D. Bohdanovych [1]) . 25. Raij Kalista Anshimkude XVIII c. (No 197 in Katalog of D. Bohdanovych [1]). 26. Tcvetosobranie Iliji Ekditu XVIII cm. (No 198 in Katalog of D. Bohdanovych [1]). 27. Izbornyk XVIII cm. (No 215 in Katalog of D. Bohdanovych [1]). 28. Mineya of februaru; 3-mя чверть XVI cm. (No 238 in Katalog of D. Bohdanovych [1]). 29. Mineya of februaru; 1708 p. (No 252 in Katalog of D. Bohdanovych [1]). 